\title{
Pengaruh Numbered Head Together (NHT) Untuk Meningkatkan Pemahaman Konsep Dan Motivasi Belajar IPS Peserta Didik Kelas II Di SD Anak Saleh
}

\author{
Mutik Nur Fadhilah \\ IAIN Madura \\ fadhilahmutik@iainmadura.ac.id \\ Mohamad Nurahman \\ SD Anak Saleh Kota Malang \\ Mohamadnurahman@sekolahanaksaleh.sch.id \\ DOI: 10.35719/educare.v2i2.72
}

\begin{abstract}
The learning process in the new normal is currently still undergoing a process of adaptation. Where the learning is still limited face-to-face and some others are brave. Process adaptation. This learning requires an NHT learning technique that makes it easier for class II students to understand the concept of social studies learning in the natural and artificial environment as a whole and is able to increase their motivation in learning. The research method uses a quantitative design using a non-equivalent control group design. The variables of this study consisted of independent variables and dependent variables. The population of this study were all second grade students at Anak Saleh Elementary School, while the samples were second grade students who carried out the bold learning process and second grade students who carried out offline learning processes. The data collection used in this study included interviews, questionnaires and observations. The data analysis technique is validity test and reliability test. Analysis of the data used through data coding, data transfer to a computer using prerequisite tests and hypothesis testing. The results of the research show: 1) the level of understanding of the social studies concept of class II students who study with the Numbered Head Together (NHT) learning technique is better than conventional learning techniques of 0.429 (results from the t-test) and 2) the level of motivation to learn social studies of class students II with Numbered Head Together (NHT) learning technique of 0.733 is better than conventional learning which is only 0.704. Surely this is greater than rtable $=0.361$.
\end{abstract}

Keywords: NHT; Concept Understanding; Motivation to Learn 


\begin{abstract}
Abstrak
Proses pembelajaran di masa new normal saat ini masih mengalami proses adaptasi. Dimana pembelajarannya masih dengan tatap muka terbatas dan sebagian lainnya daring. Adaptasi proses peralihan pembelajaran inilah dibutuhkan sebuah tekhnik pembelajaran NHT yang mempermudah peserta didik kelas II dalam memahami konsep belajar IPS dalam materi lingkungan alam dan buatan secara utuh dan mampu meningkatkan motivasinya dalam belajar. Metode penelitian menggunakan kuantitatif menggunakan desain non equeivalen control grup design. Variabel penelitian ini terdiri dari variabel bebas dan variabel terikat. Populasi penelitian ini adalah seluruh peserta didik kelas II di SD Anak Saleh, sedangkan sampelnya adalah peserta didik kelas II yang melakukan proses pembelajaran daring dan kelas II yang melakukan proses pembelajaran luring. Pengumpulan data yang digunakan dalam penelitian ini meliputi wawancara, angket dan observasi. Tehnik analisis data uji validitas dan uji reliabilitas. Analisis data yang digunakan melalui pengkodean data, pemindahan data ke komputer menggunakan uji prasyarat analisis dan uji hipotesis. Hasil penelitiannya penelitian ini menunjukkan: 1) tingkat pemahaman konsep IPS peserta didik kelas II yang belajar dengan tekhnik pembelajaran Numbered Head Together (NHT) lebih baik daripada tekhnik pembelajaran konvensional sebesar 0,429 (hasil dari uji-t) dan 2) tingkat motivasi belajar IPS peserta didik kelas II dengan tekhnik pembelajaran Numbered Head Together (NHT) sebesar 0,733 lebih baik daripada tekhnik pembelajaran konvensional yang hanya sebesar 0,704. Tentunya hal ini lebih besar daripada $\mathrm{r}$ tabel $=0,361$.
\end{abstract}

\title{
Kata Kunci: NHT; Pemahaman Konsep; Motivasi Belajar
}

\section{PENDAHULUAN}

Pendidikan saat ini mengalami perubahan selama adanya covid-19, khususnya pada jenjang sekolah dasar. Hal ini menjadikan SD Anak Saleh melakukan proses pembelajaran secara blended learning, terdapat beberapa peserta didik yang mengikuti proses pembelajaran daring. Akan tetapi terdapat beberapa peserta didik yang melakukan proses pembelajaran secara TMT (Tatap Muka Terbatas). Hal ini dilakukan sesuai dengan kebijakan pemerintah dan kebijakan lembaga SD Anak Saleh.

Kurikulum yang digunakan dalam sekolah ini berbeda dengan sekolah lainnya. Salah satunya pada jenjang kelas II pada mata pelajaran IPS, 
khususnya materi lingkungan alam dan buatan. Materi ini perlu untuk dikaji secara kongkrit agar peserta didik mampu memahami konsep dari materi lingkungan alam dan buatan. Dimana IPS merupakan sebuah bidang studi yang mengkaji masalah sosial yang bertujuan agar peserta didik lebih bertanggung jawab kepada lingkungan sekitarnya. ${ }^{1}$ Serta memotivasi peserta didik dalam proses pembelajaran pada masa transisi daring ke proses pembelajaran luring.

Mengatasi hal tersebut, peneliti menggunakan metode pembelajaran NHT (Numbered Head Together) baik pada proses pembelajaran daring maupun luring. Hal ini dapat mengantar peserta didik dalam menelaah materi yang tercakup dalam suatu pembelajaran dan pengecekan pemahaman mereka terhadap isi pembelajaran. ${ }^{2}$ Diharapkan nantinya peserta didik mampu lebih semangat dalam proses pembelajaran. Terutama dalam proses pembelajaran blended learning yang sedang dilakukan oleh SD Anak Saleh, baik secara tatap muka terbatas atau secara daring. Hal ini bersesuaian dengan makna blended learning yang mengintegrasikan proses pembelajaran secara luring maupun secara daring di masa new normal covid-19. ${ }^{3}$ Khususnya dalam materi yang mengkaji tentang lingkungan alam dan buatan.

Konteks rumusan penelitian ini, yaitu: 1) untuk menjelaskan ada tidaknya perbedaan tingkat pemahaman konsep IPS materi lingkungan alam dan buatan peserta didik kelas II yang belajar dengan tekhnik pembelajaran Numbered Head Together (NHT) lebih baik daripada tehnik pembelajaran

${ }^{1}$ Rifki Afandi, "Pengembangan Media Pembelajaran Permainan Ular Tangga Untuk Meningkatkan Motivasi Belajar Siswa Dan Hasil Belajar IPS Di Sekolah Dasar," JINoP (Jurnal Inovasi Pembelajaran) 1, no. 1 (2015): 77, https://doi.org/10.22219/jinop.v1i1.2450.

${ }^{2}$ Dian Dame Tinambunan, Maman Fathurrohman, and Etika Khaerunnisa, "Pengaruh Model Pembelajaran Kooperatif Tipe Numbered Head Together (NHT) Terhadap Kemampuan Pemecahan Masalah Matematis Siswa SMP," TIRTAMATH: Jurnal Penelitian Dan Pengajaran Matematika 2, no. 1 (2020): 30, https://doi.org/10.48181/tirtamath.v2i1.8322.

${ }^{3} \mathrm{MN}$ Fadhilah, "Blended Learning Dalam Meningkatkan Kemampuan Hots Mahasiswa Pgmi Staipana Mutik,” Jurnal Studi Islam: Pancawahana, 15, no. 1 (2020): 111-22. 
konvensional, dan 2) untuk menjelaskan ada tidaknya perbedaan tingkat motivasi belajar konsep IPS materi lingkungan alam dan buatan peserta didik kelas II dengan tekhnik pembelajaran Numbered Head Together (NHT) lebih baik daripada tekhnik pembelajaran konvensional.

Sehingga proses pembelajaran di masa new normal pada pembelajaran IPS materi lingkungan alam dan buatan lebih bermakna mampu meningkatkan pemahaman konsep dan motivasi menggunakan tekhnik pembelajaran NHT daripada tehnik pembelajaran konvensional. Hal ini terkait makna dari tehnik pembelajaran NHT sebagai sebuah kondisi peserta didik untuk berfikir bersama secara berkelompok, masing-masing kelompok diberi nomor, untuk menjawab atau mengkonfirmasi suatu permasalahan atau pertanyaan dari seorang guru. ${ }^{4}$ Dengan adanya proses berkelompok ini peserta didik mampu memahami sebuah konsep secara utuh secara bersamasama dan nantinya akan memotivasi peserta didik untuk lebih giat belajar. ${ }^{5}$ Sehingga proses penelitian ini dapat mengetahui tingkat perbedaan antara tekhnik pembelajaran NHT dengan tekhnik pembelajaran konvensional dalam proses pembelajaran IPS $^{6}$ materi lingkungan alam dan buatan pada peserta didik kelas II SD Anak Saleh Kota Malang.

\section{METODE PENELITIAN}

Penelitian ini, menggunakan pendekatan kuantitatif dengan jenis rancangan penelitian ekperimen kuasi yang menggunakan desain non equeivalen control grup design. Variabel penelitian ini terdiri dari variabel

${ }^{4}$ Sri Fatoyah, Akhmad Nayazik, and Arie Wahyuni, "Studi Komparasi Hasil Belajar Matematika Menggunakan Model Pembelajaran Kooperatif Tipe Numbered Heads Together (Nht) Dan Student Teams Achievement Division (Stad)," Al-Qalasadi : Jurnal Ilmiah Pendidikan Matematika 4, no. 1 (2020): 50-55, https://doi.org/10.32505/v3i2.1196.

${ }^{5}$ Lely Afni Ikhwandari, Nyoto Hardjono, and Gamaliel Septian Airlanda, "Peningkatan Motivasi Dan Hasil Belajar Matematika Peserta Didik Dengan Model Numbered Heads Together (Nht)," Jurnal Basicedu 3, no. 4 (2019): 2101-2112, https://doi.org/10.31004/basicedu.v3i4.283.

${ }^{6}$ Afandi, "Pengembangan Media Pembelajaran Permainan Ular Tangga Untuk Meningkatkan Motivasi Belajar Siswa Dan Hasil Belajar IPS Di Sekolah Dasar." 
bebas dan variabel terikat. Variabel bebasnya adalah tehnik pembelajaran NHT, sedangkan variabel terikatnya adalah pemahaman konsep dan motivasi belajar. Populasi penelitian ini adalah seluruh peserta didik kelas II di SD Anak Saleh, sedangkan sampelnya adalah peserta didik kelas II yang melakukan proses pembelajaran daring dan kelas II yang melakukan proses pembelajaran luring. Pengumpulan data yang digunakan dalam penelitian ini meliputi wawancara, angket dan observasi. Instrumen penelitian ini terdiri dari $\mathrm{X}, \mathrm{Y}_{1}$ dan $\mathrm{Y}_{2}$. Berdasarkan instrumen penelitian tersebut, peneliti menggunakan tekhnik analisis data uji validitas dan uji reliabilitas. Prosedur penelitian ini terdiri dari 4 tahapan yaitu: tahap persiapan dan observasi awal, pra penelitian, pengumpulan dan penelitian, finalisasi. Analisis data yang digunakan melalui pengkodean data, pemindahan data ke komputer menggunakan uji prasyarat analisis dan uji hipotesis.

\section{HASIL DAN PEMBAHASAN TEMUAN}

\section{HASIL TEMUAN}

\section{Tingkat Pemahaman Konsep Kelas Eksperimen dan Kelas Kontrol}

Dari hasil post-test peserta didik kelas eksperimen dan kelas kontrol, peneliti mulai mengelolahnya menjadi uji prasyarat dalam menguji hipotesis $^{7}$ yang berkaitan dengan pemahaman konsep peserta didik pada mata pembelajaran IPS (Ilmu Pengetahuan Sosial). Sebelum diadakan pengujian hipotesis terlebih dahulu dilakukan uji persyaratan analisis yang meliputi uji normalitas dan uji homogenitas. Setelah kedua uji tersebut sudah dilakukan barulah menggunakan uji-t untuk mengetahui adanya pengaruh atau tidaknya tekhnik pembelajaran NHT dengan tehnik pembelajaran konvensional.

Uji Asumsi dimaksudkan untuk menguji apakah nilai residual yang telah distandarisasi pada model regresi berdistribusi normal atau tidak.

${ }^{7}$ Tinambunan, Fathurrohman, and Khaerunnisa, "Pengaruh Model Pembelajaran Kooperatif Tipe Numbered Head Together (Nht) Terhadap Kemampuan Pemecahan Masalah Matematis Siswa SMP." 
Pengujian normalitas menggunakan uji Liliefors pada taraf signifikan $\alpha=$ $0,05 .{ }^{8}$ Data tidak berdistribusi normal jika $\mathrm{p}$ value (Sig.) $<0,05$. Berikut ini hasil normalitas dengan SPSS version 16 for Windows :

Tabel 1.1

Hasil Uji Asumsi Kelas Eksperimen

Tests of Normality

\begin{tabular}{|c|c|c|c|c|c|c|c|}
\hline & \multirow{2}{*}{ Kelas } & \multicolumn{3}{|c|}{ Kolmogorov-Smirnov ${ }^{\mathrm{a}}$} & \multicolumn{3}{|c|}{ Shapiro-Wilk } \\
\hline & & Statistic & Df & Sig. & Statistic & df & Sig. \\
\hline nilai & 1 & .176 & 30 & .019 & .897 & 30 & .007 \\
\hline
\end{tabular}

a. Lilliefors Significance Correction

Dari tabel kelas ekperimen di atas, maka dapat disimpulkan untuk kelas ekperimen $\mathrm{p}$ value (Sig.) sebesar 0,019. Karena $\mathrm{p}$ value (Sig.) $>0,05$ maka dapat disimpulkan bahwa data yang diambil dari populasi yang berdistribusi normal. Sebagai perbandingannya peneliti akan menyajikan pula data tabel kelas kontrol, yaitu:

Tabel 1.2

\section{Hasil Uji Asumsi Kelas Kontrol}

Tests of Normality

\begin{tabular}{|r|r|r|r|r|r|r|r|}
\hline \multirow{2}{*}{} & \multirow{2}{*}{ Kelas } & \multicolumn{3}{|c|}{ Kolmogorov-Smirnova $^{\text {a }}$} & \multicolumn{3}{|c|}{ Shapiro-Wilk } \\
\cline { 3 - 8 } & & Statistic & \multicolumn{1}{c|}{ Df } & \multicolumn{1}{c|}{ Sig. } & Statistic & df & \multicolumn{1}{c|}{ Sig. } \\
\hline nilai & 2 & .174 & 30 & .021 & .922 & 30 & .030 \\
\hline
\end{tabular}

a. Lilliefors Significance Correction

Dari tabel kelas kontrol disimpukan p value (Sig.) sebesar 0,021. Karena $\mathrm{p}$ value (Sig.) > 0,05 maka dapat disimpulkan bahwa data yang diambil dari populasi yang berdistribusi normal. ${ }^{9}$ Setelah diadakan uji asumsi, maka peneliti melakukan uji hipotesis 1 .

Uji hipotesis 1 bertujuan untuk mengetahui apakah variansi data yang akan dianalisis homogen atau tidak. Hipotesis statistik yang digunakan pada 89.

\footnotetext{
${ }^{8}$ Nuryadi Et Al., Dasar-Dasar Statistika Penelitian (Yogyakarta: Sibuku Media, 2017),

${ }^{9}$ Nuryadi Et Al. Dasar-Dasar Statistika Penelitian, 11.
} 
uji homogenitas signifikan $\alpha=0,05$. Data tidak homogen jika $p$ value (Sig.) $<0,05$. Berikut ini hasil homogenitas dengan SPSS version 16 for Windows antara lain:

Tabel 1.3

Hasil Uji Homogenitas

Test of Homogeneity of Variances

\begin{tabular}{|c|c|c|c|}
\hline Levene Statistic & df1 & df 2 & Sig. \\
\hline 3.111 & 1 & 58 & .083 \\
\hline
\end{tabular}

Dari tabel homogenitas maka dapat disimpulkan untuk p value (Sig.) sebesar 0,083. Karena p value (Sig.) > 0,05 maka dapat disimpulkan bahwa variansi data yang pada tiap kelompok data adalah sama (homogen). Untuk mengetahui ada tidaknya pengaruh tekhnik pembelajaran NHT pada pemahaman konsep IPS, pengujian dilakukan dengan uji-t. ${ }^{10}$ Pada taraf signifikansi $\alpha=0,05$. Data tidak signifikan jika $\mathrm{p}$ value $($ Sig. $)<0,05$. Berikut ini hasil uji-t dengan SPSS version 16 for Windows :

Tabel 1.4

Hasil Uji-T Perbedaan Pemahaman Konsep IPS Menggunakan Tekhnik Pembelajaran NHT dan Tekhnik Pembelajaran Konvensional

\begin{tabular}{|c|c|c|c|c|c|c|c|c|c|c|}
\hline \multicolumn{11}{|c|}{ Independent Samples Test } \\
\hline & & \multicolumn{2}{|c|}{$\begin{array}{l}\text { Levene's Test for Equality of } \\
\text { Variances }\end{array}$} & \multicolumn{7}{|c|}{ t-test for Equality of Means } \\
\hline & & \multirow[b]{2}{*}{$\mathrm{F}$} & \multirow[b]{2}{*}{ Sig. } & \multirow[b]{2}{*}{ t } & \multirow[b]{2}{*}{ df } & \multirow[b]{2}{*}{ Sig. (2-tailed) } & \multirow{2}{*}{$\begin{array}{l}\text { Mean } \\
\text { Difference }\end{array}$} & \multirow{2}{*}{$\begin{array}{l}\text { Std. Error } \\
\text { Difference }\end{array}$} & \multicolumn{2}{|c|}{$\begin{array}{l}\text { 95\% Confidence Interval of the } \\
\text { Difference }\end{array}$} \\
\hline & & & & & & & & & Lower & Upper \\
\hline \multirow[t]{2}{*}{ nilai } & Equal variances assumed & 3.111 & .083 & .796 & 58 & .429 & 4.167 & 5.233 & -6.308 & 14.641 \\
\hline & Equal variances not assumed & & & .796 & 55.276 & .429 & 4.167 & 5.233 & -6.319 & 14.652 \\
\hline
\end{tabular}

Diketahui bahwa $F_{\text {hitung }}$ pada tabel hasil uji-t perbedaan pemahaman konsep IPS menggunakan tekhnik pembelajaran NHT dan tekhnik pembelajaran konvensional adalah 3,111 dengan probabilitas (sig.) 0,083. Karena probabilitas (sig.) 3,111 > 0,05 maka $\mathrm{H}_{0}$ diterima. Kesimpulannya bahwa pemahaman konsep IPS menggunakan tekhnik pembelajaran NHT dan tekhnik pembelajaran konvensional adalah sama atau tidak berbeda

${ }^{10}$ Nuryadi Et Al. Dasar-Dasar Statistika Penelitian, 95. 
secara signifikan. ${ }^{11}$ Dengan demikian, maka untuk pengujian rata-rata $(t$ test) mengacu pada kolom baris asumsi varian sama.

Untuk mengetahui perbedaan pemahaman konsep IPS menggunakan tekhnik pembelajaran NHT dan tekhnik pembelajaran konvensional ketentuannya sebagai berikut:

$\mathrm{H}_{0} \quad$ : tidak terdapat perbedaan pengaruh yang signifikan antara pemahaman konsep IPS menggunakan tekhnik pembelajaran NHT dan tekhnik pembelajaran konvensional.

$\mathrm{H}_{\mathrm{a}} \quad$ : terdapat perbedaan pengaruh yang signifikan antara pemahamn konsep IPS menggunakan tekhnik pembelajaran NHT dan tekhnik pembelajaran konvensional.

Diketahui nilai thitung pemahman konsep IPS menggunakan tekhnik pembelajaran NHT dan tekhnik pembelajaran konvensional adalah 0, 796 dengan probabilitas (sig.) 0,429. Karena probabilitas (sig.) 0,429>0,05 maka $\mathrm{H}_{0}$ ditolak. Artinya terdapat perbedaan yang signifikan antara pemahaman konsep IPS menggunakan tekhnik pembelajaran NHT dan tekhnik pembelajaran konvensional. Berdasarkan hasil pengelolahan tersebut, maka dapat disimpulkan bahwa pemahaman konsep dengan menggunakan tekhnik pembelajaran NHT dan tekhnik pembelajaran konvensional memiliki perbedaan yang signifikan. ${ }^{12}$

\section{Tingkat Motivasi Kelas Eksperimen dan Kelas Kontrol}

Berdasarkan hasil analisis pengujian validitas kelas kontrol, didapat nilai korelasi untuk semua item-item tersebut berkorelasi signifikan dengan skor total (valid) karena lebih dari $r$ tabel yaitu 0,361. Sehingga angket yang telah diuji hasilnya valid ketika proses pengambilan motivasi belajar IPS.

\footnotetext{
${ }^{11}$ Rob Thew et al., "Perbedaan Metode Pembelajaran Kooperatif Numbered Heads Together (Nht) Dan Konvensional Terhadap Hasil Belajar Askeb Patologi Pada Mahasiswa D-III," Metrologia 53, no. 5 (2015): 1-116. 13.

${ }^{12}$ Candra Kusuma Lestari, "Penerapan Metode Number Heads Together (NHT) Untuk Meningkatkan Keaktifan Dan Hasil Belajar Siswa Terhadap Mata Pelajaran Mulok Produktif Membuat Jajanan Tradisional Kelas X TPHP II Di SMK N 1 PANDAK Tahun Ajaran 2014/2015," Skripsi, 2015, 1-192, 22.
} 
Uji reliabilitas adalah konsistensi dari serangkaian pengukuran atau serangakaian alat. Berikut ini hasil reliabilitas dengan menggunakan SPSS version 16 for Windows :

Tabel 1.5

Hasil Uji Realibilitas

\begin{tabular}{|c|c|c|c|}
\hline Skala & $\begin{array}{c}\text { Cronbach's } \\
\text { Alpha }\end{array}$ & Koefisien r & Keterangan \\
\hline Eksperimen & 0,733 & 0,361 & Reliable \\
\hline Kontrol & 0,704 & 0,361 & Reliable \\
\hline
\end{tabular}

Dari hasil analisis didapat nilai Alpha kelas ekperimen sebesar 0,733 dan Alpha kelas kontrol yaitu 0,704. Jika nilai r kritis (uji 2 sisi) pada signifikansi $5 \%$ dengan $\mathrm{n}=30$, didapat sebesar 0,361. Maka dapat disimpulkan bahwa butir instrumen penelitian tersebut reliable.

\section{PEMBAHASAN TEMUAN}

Tingkat Pemahaman Konsep IPS Materi Lingkungan Alam Dan Buatan Peserta Didik Kelas II Yang Belajar Dengan Teknik

\section{Pembelajaran Numbered Head Together (NHT)}

Berdasarkan temuan penelitian yang telah peneliti temukan, menunjukkan adanya persamaan prosentase dalam melakukan kegiatan pretest sebesar 54, 83\%. Maka dapat disimpulkan bahwa kedua kelas ini memiliki kemampuan kognitif (pengetahuan) yang sama sehingga dapat diuji kemampuannya menggunakan treatmen yang berbeda dalam pembelajaran IPS.

Peneliti melakukan kegiatan post-test untuk mengukur adanya perbedaan pemahaman konsep IPS. Dengan demikian, peneliti menemukan bahwa kelas eksperimen memiliki nilai post-test sebesar 70,83\%. Sedangkan kelas kontrol nilai post-testnya sebesar $66,67 \%$. 
Hasil data mentah post-test tersebut, peneliti analisis kembali menggunakan uji prasyarat dan uji hipotesis. Sehingga menghasilkan nilai $\mathrm{t}_{\text {hitung }}=0,796$ dengan nilai probabilitas $($ sig. $)=0,429$. Artinya, peserta didik kelas eksperimen yang menggunakan tekhnik pembelajaran NHT lebih baik dalam memahami konsep IPS materi lingkungan alam dan buatan daripada peserta didik kelas kontrol.

Tentunya hasil penelitian ini, bersesuaian dengan teori Numbered Head Together (NHT) memiliki tujuan agar pemahaman peserta didik saat bercerita yang diberikan dalam tugas kelompok, peserta didik dapat saling menambah kekurangan pembendaharaan kata dalam merangkai kembali cerita yang dipelajarinya, karena ada kerjasama itulah diharapkan peserta didik tidak mengalami kesulitan dalam menceritakan cerita yang dipelajarinya. ${ }^{13}$ Teori ini menunjukkan bahwa dengan menggunakan tekhnik pembelajaran NHT peserta didik lebih memahami sebuah konsep IPS secara utuh dengan melakukan kerjasama dengan teman-temannya. Serta melatih aspek afektif (sikap) dan psikomotoriknya (keterampilan) dalam melakukan interaksi dengan teman-temannya.

Keterlibatan total semua peserta didik dan merupakan upaya yang sangat baik untuk meningkatkan tanggung jawab peserta didik dan memberikan kesempatan kepada peserta didik untuk membagikan ide-ide jawaban yang paling tepat. ${ }^{14}$ Dengan adanya keterlibatan total semua peserta didik dalam pembelajaran IPS menggunakan tehnik NHT dapat memudahkan pemahaman konsep peserta didik dalam mengembangkan pengetahuannya. Terdapat perbandingan kelebihan antara tehnik

\footnotetext{
${ }^{13}$ Ahmad Susanto, Pengembangan Pembelajaran IPS di SD/MI, (Jakarta: Prenamedia Group, 2014), 229.

14 M. Nur, dan PR. Wikandari. Pengajaran Berpusat pada Peserta didik dan Pendekatan Konstruktivis dalam Pengajaran. (Surabaya: Universitas Negeri Surabaya, 2000), 78.
} 
pembelajaran Numbered Head Together dengan tekhnik pembelajaran konvensional, yaitu: ${ }^{15}$

Tabel 1.6

Kelebihan Numbered Head Together dan Konvensional

\begin{tabular}{|c|c|}
\hline Numbered Head Together & Konvensional \\
\hline Meningkatkan prestasi belajar & Pembelajaran lebih cepat selesai \\
\hline $\begin{array}{l}\text { Meningkatkan pemahaman konsep } \\
\text { peserta didik }\end{array}$ & $\begin{array}{l}\text { Fokus pada penggunaan metode } \\
\text { ceramah }\end{array}$ \\
\hline $\begin{array}{l}\text { Meningkatkan rasa percaya diri } \\
\text { peserta didik }\end{array}$ & $\begin{array}{l}\text { Peserta didik lebih cenderung } \\
\text { mendengarkan }\end{array}$ \\
\hline $\begin{array}{l}\text { Meningkatkan rasa memiliki dan } \\
\text { kerjasama }\end{array}$ & Kemampuan audio lebih tinggi \\
\hline $\begin{array}{l}\text { Peserta didik lebih siap untuk } \\
\text { proses pembelajaran }\end{array}$ & $\begin{array}{l}\text { Peserta didik yang pandai akan } \\
\text { cepat memahami proses } \\
\text { pembelajaran }\end{array}$ \\
\hline $\begin{array}{l}\text { Proses diskusi dapat dilakukan } \\
\text { secara sungguhan oleh peserta didik }\end{array}$ & $\begin{array}{l}\text { Gerak cepat dalam proses } \\
\text { penyelesaian materi }\end{array}$ \\
\hline $\begin{array}{l}\text { Peserta didik yang pandai dapat } \\
\text { membantu peserta didik yang } \\
\text { kurang pandai }\end{array}$ & $\begin{array}{l}\text { Guru lebih fokus pada materi dan } \\
\text { peserta didik dalam proses } \\
\text { pemahaman pengetahuan }\end{array}$ \\
\hline $\begin{array}{lrr}\text { Meningkatkan } & \text { interaksi } & \text { peserta } \\
\text { didik dalam } & \text { menjawab } & \text { sebuah } \\
\text { persoalan } & & \end{array}$ & $\begin{array}{l}\text { Interaksi terjadi antara guru dan } \\
\text { siswa }\end{array}$ \\
\hline $\begin{array}{l}\text { Menimbulkan suasana kelas yang } \\
\text { gembira dan antusias belajar } \\
\text { peserta didik meningkat }\end{array}$ & $\begin{array}{l}\text { Anak lebih fokus pada pengetahuan } \\
\text { yang dipelajari sesuai dengan } \\
\text { tujuan }\end{array}$ \\
\hline
\end{tabular}

Berdasarkan tabel di atas, menunjukkan adanya kelebihan masingmasing tehnik pembelajaran antara NHT dan konvensional. Teknik pembelajaran konvensional merupakan sebuah proses pembelajaran yang dilakukan secara tradisional oleh para guru. Tehnik ini digunakan untuk meningkatkan kemampuan peserta didik dalam memahami sebuah materi pembelajaran secara cepat menggunakan metode ceramah.

15 Aris Shoimin, 68 Model Pembelajaran Inovatif dalam Kurikulum 2013, (Yogjakarta: ArRuzz Media, 2014), 108-109. 
Berbeda halnya dengan Numbered Head Together, merupakan sebuah tehnik pembelajaran yang terfokus pada sebuah perubahan proses pembelajaran yang lebih interaktif antara guru dan peserta didik. Di masa new normal ini diperlukan perubahan tehnik pembelajaran yang mampu meningkatkan percaya diri peserta didik dalam berdiskusi dan meningkatkan kemampuan komunikasinya. Dimana pada pembelajaran IPS siswa mampu meningkatkan pengetahuan belajarnya tentang lingkungan alam dan buatan secara luas dan sesuai dengan pemahaman yang dimilikinya.

Tingkat Motivasi Belajar IPS Materi Lingkungan Alam Dan Buatan Peserta Didik Kelas II Dengan Teknik Pembelajaran Numbered Head

\section{Together (NHT)}

Sebelum proses pembelajaran menggunakan tekhnik pembelajaran konvensional yang membuat peserta didik kurang moodnya dalam mengikuti proses pembelajaran di masa new normal. Sehingga semangat peserta didik di proses pembelajaran TMT cenderung kurang bersemangat dan malas dalam mengikuti pembelajaran di kelas. Begitu pun dengan peserta didik yang mengikuti kelas daring, lebih cenderung banyak yang melamun bahkan tertidur saat kelas berlangsung.

Setelah guru menggunakan tehnik pembelajatan NHT, peserta didik yang melakukan proses pembelajaran secara daring maupun TMT semakin antusias dalam mengikuti pembelajaran. Hal ini karena terdapat banyak variasi proses pembelajaran peserta didik, yang mampu menggugah semangat peserta didik dalam berinterkasi dengan peserta didik lainnya. Serta meningkatkan rasa ingin tahu dalam menanggapi berbagai macam materi yang diberikan guru terutama dalam mata pelajaran IPS pada materi lingkungan alam dan buatan.

Berdasarkan uji validitas per-item, peneliti mendapatkan semua hasil per-item adalah valid. Hal ini dikarenakan $r_{\text {hitung }}>r_{\text {tabel, }}$ setelah melakukan uji validitas, peneliti mampu melanjutkan uji reliabilitas antara kelas eskperimen dan kelas kontrol. Kelas eksperimen menunjukkan adanya nilai 
sebesar 0,733 atau 73,3\% lebih banyak daripada kelas kontrol yang nilainya sebesar 0,704 atau 70,4\% saja. Keduanya memiliki tingkat reliabilitas yang lebih besar daripada $r$ tabel sebesar 0,361. Akan tetapi kelas eksperimen memiliki nilai yang lebih tinggi daripada kelas kontrol. Hal ini menunjukkan adanya pengaruh motivasi belajar menggunkan tekhnik pembelajaran NHT lebih tinggi daripada tekhnik pembelajaran konvensional.

Hal ini tentunya bersesuaian keterlibatan total semua peserta didik dalam metode Numbered Head Together (NHT) akan berdampak positif terhadap motivasi belajar dan peserta didik akan berusaha memahami konsep-konsep ataupun pemecahan masalah yang disajikan oleh guru. ${ }^{16}$ Pembelajaran kooperatif tipe NHT merupakan salah satu tipe pembelajaran kooperatif yang menekankan pada struktur-struktur khusus yang dirancang untuk mempengaruhi pola-pola interaksi peserta didik dalam memiliki tujuan untuk meningkatkan penguasaan akademik dan motivasi belajar peserta didik. ${ }^{17}$ Tentunya ini membuktikan bahwa dengan menggunakan tekhnik pembelajaran NHT peserta didik mampu meningkatkan pemahaman konsep dan motivasi belajarnya. Dengan adanya motivasi belajar yang tinggi menggunakan tekhnik pembelajaran NHT, ${ }^{18}$ menimbulkan dorongan yang positif bagi peserta didik untuk lebih memahami IPS materi lingkungan alam dan buatan. Hal ini membuktikan semakin menarik tehnik pembelajaran yang dilakukan guru akan meningkatkan motivasi belajar

\footnotetext{
${ }^{16}$ Muslimin Ibrahim dan M. Nur, Pembelajaran Kooperatif, (Surabaya: UNESA, 2002), 7.

${ }^{17}$ Lely Afni Ikhwandari, Nyoto Hardjono, and Gamaliel Septian Airlanda, "Peningkatan Motivasi Dan Hasil Belajar Matematika Peserta Didik Dengan Model Numbered Heads Together (NHT)," Jurnal Basicedu 3, no. 4 (2019): 2101-2112Peningkatan Motivasi Dan Hasil Belajar Ma, https://doi.org/10.31004/basicedu.v3i4.283.

18 Sri Fatoyah, Akhmad Nayazik, and Arie Wahyuni, "Studi Komparasi Hasil Belajar Matematika Menggunakan Model Pembelajaran Kooperatif Tipe Numbered Heads Together (Nht) Dan Student Teams Achievement Division (Stad)," Al-Qalasadi : Jurnal Ilmiah Pendidikan Matematika 4, no. 1 (2020): 50-55, https://doi.org/10.32505/v3i2.1196.
} 
peserta didik lebih baik dalam mengikuti proses pembelajaran. ${ }^{19}$ Meskipun peserta didik dalam masa peralihan proses pembelajaran daring ke tatap muka terbatas tetap semangat mengikuti proses pembelajaran sesuai arahan guru.

\section{SIMPULAN}

Berdasarkan hasil penelitian yang peneliti lakukan dapat menarik beberapa kesimpulan berdasarkan temuan penelitian ini, antara lain: (1) Tingkat pemahaman konsep IPS peserta didik kelas II yang belajar dengan menggunakan tekhnik pembelajaran NHT lebih baik daripada menggunakan tekhnik pembelajaran konvensional sebesar 0,429 (hasil dari uji-t). (2) Tingkat motivasi belajar IPS peserta didik kelas II dengan tekhnik pembelajaran Numbered Head Together (NHT) sebesar 0,733 lebih baik daripada tekhnik pembelajaran konvensional yang hanya sebesar 0,704. Tentunya hal ini lebih besar daripada $\mathrm{r}$ tabel $=0,361$.

\section{DAFTAR PUSTAKA}

Afandi, Rifki. "Pengembangan Media Pembelajaran Permainan Ular Tangga Untuk Meningkatkan Motivasi Belajar Siswa Dan Hasil Belajar IPS Di Sekolah Dasar." JINoP (Jurnal Inovasi $\begin{array}{lllll}\text { Pembelajaran) } & 1, & \text { no. } & 1 & \text { (2015): }\end{array}$ https://doi.org/10.22219/jinop.v1i1.2450.

Susanto, Ahmad. Pengembangan Pembelajaran IPS di SD/MI. Jakarta: Prenamedia Group. 2014.

${ }^{19}$ Hilde Gardis Spriani, Nurul Ain, and Hestiningtyas Yuli Pratiwi, "Pengaruh Model Pembelajaran Problem Based Learning Disertai Metode Scaffolding Dan Motivasi Belajar," Jurnal Terapan Sains \& Teknologi 1, no. 2 (2019): 29-40. 
Shoimin, Aris. 68 Model Pembelajaran Inovatif dalam Kurikulum 2013. Yogjakarta: ArRuzz Media. 2014.

Ikhwandari, Lely Afni, Nyoto Hardjono, and Gamaliel Septian Airlanda. "Peningkatan Motivasi Dan Hasil Belajar Matematika Peserta Didik Dengan Model Numbered Heads Together (Nht)." Jurnal Basicedu 3, no. 4 (2019): 2101-2112. https://doi.org/10.31004/basicedu.v3i4.283.

Lestari, Candra Kusuma. "Penerapan Metode Number Heads Together (NHT) Untuk Meningkatkan Keaktifan Dan Hasil Belajar Siswa Terhadap Mata Pelajaran Mulok Produktif Membuat Jajanan Tradisional Kelas X TPHP II Di SMK N 1 PANDAK Tahun Ajaran 2014/2015." Skripsi, 2015, 1-192.

Ibrahim, Muslimin dan M. Nur, Pembelajaran Kooperatif. Surabaya: UNESA. 2002.

M. Nur, dan PR. Wikandari. Pengajaran Berpusat pada Peserta didik dan Pendekatan Konstruktivis dalam Pengajaran. Surabaya: Universitas Negeri Surabaya. 2000.

MN Fadhilah. "Blended Learning Dalam Meningkatkan Kemampuan HOTS Mahasiswa PGMI STAIPANA." Jurnal Studi Islam: Pancawahana, 15, no. 1 (2020): 111-22.

Nuryadi, Tutut Dewi Astuti, Endang Sri Utami, And Martinus Budiantara. Dasar-Dasar Statistika Penelitian. Yogyakarta: SIBUKU MEDIA. 2017.

Rabbani, FA. "Pengaruh Pemakaian Jilbab Terhadap Perilaku Moral Mahasiswi (Studi Kuantitatif Deskriptif Di FKIP Universitas Pasundan)," 2016, 15-50.

Spriani, Hilde Gardis, Nurul Ain, and Hestiningtyas Yuli Pratiwi. "Pengaruh Model Pembelajaran Problem Based Learning Disertai Metode Scaffolding Dan Motivasi Belajar." Jurnal Terapan Sains \& Teknologi 1, no. 2 (2019): 29-40.

Sri Fatoyah, Akhmad Nayazik, and Arie Wahyuni. "Studi Komparasi Hasil Belajar Matematika Menggunakan Model Pembelajaran Kooperatif Tipe Numbered Heads Together (Nht) Dan Student Teams Achievement Division (Stad)." Al-Qalasadi: Jurnal Ilmiah Pendidikan Matematika 4, no. 1 (2020): 50-55. https://doi.org/10.32505/v3i2.1196.

Thew, Rob, Tommaso Calarco, Peter David Roorda, Ottawa Ca, Kevan Peter Jones, Kanata Ca, Peter Friesen, et al. "Perbedaan Metode Pembelajaran Kooperatif Numbered Heads Together (NHT) Dan Konvensional Terhadap Hasil Belajar Askeb Patologi Pada 
Mahasiswa D-III." Metrologia 53, no. 5 (2015): 1-116.

Tinambunan, Dian Dame, Maman Fathurrohman, and Etika Khaerunnisa.

"Pengaruh Model Pembelajaran Kooperatif Tipe Numbered Head Together (Nht) Terhadap Kemampuan Pemecahan Masalah Matematis Siswa SMP." TIRTAMATH: Jurnal Penelitian Dan $\begin{array}{llllll}\text { Pengajaran } & \text { Matematika 2, no. } 1 & \text { (2020): } 30 .\end{array}$ https://doi.org/10.48181/tirtamath.v2i1.8322.

Yanti, Ni Made Dwi Wisma, I Gusti Ngurah Japa, and I Made Tegeh. "Pengaruh Model Pembelajaran Kooperatif Tipe NHT Dan Motivasi Belajar Terhadap Hasil Belajar IPA." E-Journal PGSD Universitas Pendidikan Ganesha Jurusan PGSD 5, no. 2 (2017): 1-12. 